\title{
Trener sportowy dorosłych osób z niepełnosprawnością intelektualną jako ich przywódca $w$ społeczeństwie
}

\section{KEYWORDS}

people with intellectual disability, sport as a therapy, trainer as a leader, leader

\begin{abstract}
Artur Świstek, Trener sportowy dorosłych osób z niepełnosprawnością intelektualną jako ich przywódca w społeczeństwie [Sports coach of adults with intellectual disabilities as their leader in socjety]. Kultura - Społeczeństwo - Edukacja nr 2(20) 2021, Poznań 2021, pp. 329-340, Adam Mickiewicz University Press. ISSN 2300-0422, ISSN (Online) 2719-2717. DOI 10.14746/kse.2021.20.21

The article in a person representing the trait of an individual trait and a person of a sports trainer with intellectual disability and a personality traits leader with an intellectual personality and a personality traits leader with an intellectual personality.
\end{abstract}

\section{Wstęp}

W obecnych czasach najgłośniej jest o sportowcach, którzy biją rekordy na olimpiadach. O tych, co strzelają piękne bramki i wygrywają mecze. Trenerom poświęca się parę słów. A to właśnie trener jest osobą, od której najwięcej zależy. To on wychowuje, szkoli i motywuje. To on staje się liderem, wiodącym zawodników do sukcesu. Szczególnego charakteru nabiera praca trenera osób z niepełnosprawnością intelektualną. Szkoleniowiec pracujący z tą grupą musi bowiem dodatkowo wykazać się cierpliwością, zrozumieniem, empatią. Powinien być też dobrym psychologiem i znać specyfikę sportu niepełnosprawnych.

\footnotetext{
* ORCID: https://orcid.org/0000-0003-4023-4138.
} 
Dokonując wyboru problematyki, wziąłem przede wszystkim pod uwagę swoje doświadczenia. Otóż od siódmego roku życia uprawiam piłkę nożną, a od 15 lat pracuję z osobami z niepełnosprawnością intelektualną. Przeszedłem wszystkie szczeble kariery sportowej: kilkuletniego trampkarza, kilkunastoletniego juniora i dorosłego gracza - reprezentanta profesjonalnej piłki seniorskiej. Mimo że nie spełniłem swoich dziecięcych marzeń o karierze wybitnego piłkarza, to postanowiłem swoją wiedzę i umiejętności przekazywać innym. Swój warsztat trenerski doskonaliłem, współpracując z wieloma, mniej lub bardziej sławnymi, trenerami. Obecnie prowadzę zajęcia sportowe z osobami niepełnosprawnymi intelektualnie. Jestem szczęśliwy, bo dzięki tej pracy rozwinąłem się - miałem możliwość doskonalenia umiejętności sportowych oraz interpersonalnych.

Trenowanie osób z niepełnosprawnością intelektualną pozwoliło mi dostrzec nieco inną naturę sportu. Wobec tego w przyszłości chcę kontynuować moją działalność i pomagać tym, którzy zaczynają swoją przygodę oraz mają wielkie marzenia sportowe. Jestem pełen podziwu i szacunku dla ludzi niepełnosprawnych, którzy uprawiają sport zespołowy.

Zdaję sobie również sprawę z roli, jaką w przypadku tych osób odgrywa trener. Dlatego celem artykułu jest przedstawienie trenera jako lidera, którego właściwości, umiejętności i zdolności są podstawą nawiązania owocnej współpracy z zawodnikami niepełnosprawnymi intelektualnie, co służy ich lepszemu funkcjonowaniu w społeczeństwie.

\section{Specyfika przywództwa i jego rola w organizacjach pozarządowych}

Przywództwo jest to zarówno proces, jak i pewna właściwość. Jako proces przywództwo polega na używaniu wpływu, bez sięgania po środki przymusu, z zamiarem kształtowania celów grupy lub organizacji, motywowanie zachowań nastawionych na osiąganie tych celów oraz dopomożenie w ustaleniu kultury grupy lub organizacji. Jako właściwość przewodzenie jest zestawem cech przypisywanych jednostkom, które spostrzega się jako przywódców. W latach 30. XX wieku terminu „przywództwo” używano zamiennie ze słowami „kierowanie” i „zarządzać". Kolejne lata i badania dowiodły, że terminy te różnią się. Jak pisał W. Bennis: „Przywództwo nie oznacza zarządzania. Różnica między nimi jest zasadnicza. Zarządzać to zorganizować, wykonać, odpowiadać za coś, natomiast przywództwo to wpływanie, wytaczanie, kierowanie, działanie, opinie" (Kożusznik, 2005: 103). Dziś pojęcia „przywództwo” i „zarządzanie”, nie są uważane za tożsame. Różnice 
między przywódcami a menadżerami polegają głównie na innych „wymaganych” zadaniach i umiejętnościach.

Liderów wyróżnia innowacyjność i tendencja do zmiany dotychczasowych reguł postępowania i zwyczajów. Ich zadaniem jest wyznaczanie dalekiego i ambitnego celu oraz mobilizacja podwładnych do podążania w tym kierunku, natomiast menedżer powinien zarządzać uruchomionymi procesami, koncentrować się na obserwacji wyników, porównywać je z celami i korygować odchylenia. Do sprawnego funkcjonowania organizacja potrzebuje zarówno zarządzania jak i przywództwa. Przywództwo jest niezbędne do tworzenia zmian, a zarządzanie jest niezbędne do systematycznego uzyskiwania wyników. Zarządzanie w powiązaniu z przywództwem może być źródłem systematycznych zmian, a przywództwo w połączeniu z zarządzaniem pozwala na utrzymanie właściwego poziomu zgodności organizacji z jej otoczeniem (Koźmiński, Jemielniak, 2008: 87).

\section{Różnice pomiędzy przewodzeniem a zarządzaniem zawarto w tabeli 1.}

Tabela 1. Różnice między zarządzaniem i przywództwem

\begin{tabular}{|c|c|c|}
\hline Działalność & Zarządzanie & Przywództwo \\
\hline $\begin{array}{l}\text { Tworzenie } \\
\text { programu }\end{array}$ & $\begin{array}{l}\text { Planowanie i sporządzanie budżetu. Usta- } \\
\text { lanie szczegółowych kroków i harmono- } \\
\text { gramów do osiągania potrzebnych wyni- } \\
\text { ków; alokacja zasobów niezbędnych do } \\
\text { uzyskania tych wyników. }\end{array}$ & $\begin{array}{l}\text { Ustalanie kierunku. Wypracowanie wizji } \\
\text { przyszłości, często odległej, oraz strategii } \\
\text { mającej doprowadzić do zmian potrzeb- } \\
\text { nych do urzeczywistnienia tej wizji. }\end{array}$ \\
\hline $\begin{array}{l}\text { Opracowanie } \\
\text { ludzkiej sieci } \\
\text { do realizacji } \\
\text { programu }\end{array}$ & $\begin{array}{l}\text { Organizowanie i zatrudnianie. Ustalanie } \\
\text { pewnej struktury do spełniania wymogów } \\
\text { planu, obsadzanie jej ludźmi, delegowanie } \\
\text { odpowiedzialności i władzy formalnej do } \\
\text { wykonania planu, zapewnienie polityki } \\
\text { i procedur pomagających kierować ludź- } \\
\text { mi oraz tworzenie metod lub systemów do } \\
\text { obserwacji wykonania. }\end{array}$ & $\begin{array}{l}\text { Nadawanie kierunku działaniom ludzi. } \\
\text { Przekazywanie kierunku słowami i czy- } \\
\text { nami wszystkim tym, których współpraca } \\
\text { może być potrzebna, tak by wpłynąć na } \\
\text { tworzenie zespołów i koalicji, które będą } \\
\text { rozumiały i akceptowały wizję i strategię. }\end{array}$ \\
\hline $\begin{array}{l}\text { Wykonywanie } \\
\text { planów }\end{array}$ & $\begin{array}{l}\text { Kontrolowanie i rozwiązywanie proble- } \\
\text { mów. Szczegółowa obserwacja wyników } \\
\text { na tle planów, identyfikowanie odchyleń, } \\
\text { a następnie planowanie i organizowanie, } \\
\text { rozwiązywanie tych problemów. }\end{array}$ & $\begin{array}{l}\text { Motywowanie i inspirowanie. Wyzwala- } \\
\text { nie energii ludzi w celu przezwyciężania } \\
\text { głównych barier politycznych, biurokra- } \\
\text { tycznych i barier po stronie zasobów, przez } \\
\text { zaspokajanie bardzo podstawowych, lecz } \\
\text { często niezaspokojonych potrzeb ludzkich. }\end{array}$ \\
\hline Wyniki & $\begin{array}{l}\text { Stwarza pewien zakres przewidywalno- } \\
\text { ści i porządku i może w sposób systema- } \\
\text { tyczny wytwarzać podstawowe wyniki } \\
\text { oczekiwane przez różnych zainteresowa- } \\
\text { nych (np. klientów, zawsze mieszcząc się } \\
\text { w harmonogramie; akcjonariuszy, zawsze } \\
\text { mieszcząc się w budżecie). }\end{array}$ & $\begin{array}{l}\text { Powoduje zmianę, często decydującą; } \\
\text { umożliwia uzyskanie niezwykle użytecz- } \\
\text { nych zmian (np. nowych wyrobów ocze- } \\
\text { kiwanych przez klientów, nowych podejść } \\
\text { do stosunków pracy, które pomagają } \\
\text { zwiększyć konkurencyjność firmy). }\end{array}$ \\
\hline
\end{tabular}

Źródło: Koźmiński, Jemielniak, 2008: 89 
W wyniku analizy silnych i słabych stron przywódców powstała koncepcja przywódcy transakcyjnego, „który prowadzi nieustanną wymianę ze swymi podwładnymi co jest konsekwencją odmienności ich interesów. Lider dąży do osiągnięcia jak największej efektywności, używając kombinacji władzy formalnej i nieformalnego wpływu. Rozpoznaje, modyfikuje i spełnia potrzeby i oczekiwania podwładnych oraz reaguje na zmieniające się sytuacje. Przywódcy transakcyjni instrumentalnie traktują strukturę organizacyjną, formalne nagrody i kary - manipulują nimi w celu uzyskania pożądanych warunków, które wywołują pożądane zachowania" (Griffin, 2009: 44).

Podsumowując, warto podkreślić, że przywództwo polega na budowaniu przekonania co do pewnych wartości, nie jest nastawione na szybkie efekty, a raczej na powolny rozwój i dojrzewanie. Ważnym elementem jest umiejętność przystosowywania się lidera do nowych warunków i dokonywanie zmian otoczenia stosownie do potrzeb.

Lider dysponuje pewnym wrodzonym potencjałem, który może rozwinąć. W ciągu całego życia uczy się odpowiednich zachowań i zdobywa wiedzę oraz umiejętności. Skuteczni przywódcy nie wyróżniają się określonym zbiorem szczególnych cech, jednak charakteryzują się zachowaniami, których można się nauczyć. Charyzmatyczny przywódca ma „skrajnie wysoki poziom wiary w siebie, dominacji i przekonanie o moralnej słuszności wyznawanych przez siebie poglądów" albo przynajmniej umiejętność przekonania swoich zwolenników, że ma taką wiarę i przekonanie (Griffin, 2009: 44).

\subsection{Organizacje pozarządowe}

Organizacja pozarządowa to „organizacja niezwiązana z żadną władzą państwową, która nie korzysta z rządowej pomocy finansowej. Należą do niej zrzeszenia narodowe, stowarzyszenia pozarządowe oraz osoby fizyczne lub prawne z różnych państw. Jej działalność opiera się na statutach nie mających charakteru umów międzynarodowych. Nie są nastawione na osiąganie zysku, a zaspokajanie jakichś potrzeb" (Naglak, 1999: 14). To nie oznacza jednak, że organizacja nie może prowadzić działalności gospodarczej. W takim wypadku dochody nie są dzielone pomiędzy osoby pracujące czy ochotników, ale przeznaczane na dalszą działalność.

Spełniają również funkcje związane z realizacją potrzeb szerszej społeczności:

- funkcja integracyjna - proces budowania więzi społecznych, zbliżania jednostek, a także całych narodów;

- funkcja opiekuńczo-wychowawcza - związana z kształtowaniem osobowości. Dotyczy roli, jaką powinno odgrywać środowisko lokalne w procesie wychowawczym dzieci i młodzieży oraz całych rodzin i grup społecznych; 
- funkcja normalizacyjna - płaszczyzna harmonizowania działalności społecznej z wymaganiami prawnymi, należy do niej sfera rehabilitacji i opieki nad osobami z niepełnosprawnością intelektualną, resocjalizacji osób nieprzystosowanych społecznie, pomocy osobom uzależnionym i bezdomnym;

- funkcja grupy nacisku - obrona podstawowych wartości społeczeństwa demokratycznego: pluralizmu, wolności, poszanowania interesów i wspólnego dobra;

- funkcja uspołeczniania państwa - stanowi pewnego rodzaju podsumowanie funkcji przedstawionych powyżej (Naglak, 1999: 20).

\section{Organizacje sportowe jako miejsce dla liderów}

„Sport jest częścią dziedzictwa każdego człowieka i nic nigdy go nie zastąpi” Pierre de Coubertin (Biała księga na temat sportu, 2007: 6)

Sport „przybiera na znaczeniu jako zjawisko społeczne i gospodarcze, przyczyniając się w dużym stopniu do realizacji strategicznych celów Unii Europejskiej, takich jak solidarność i dobrobyt. Olimpijski ideał rozwoju sportu propagującego pokój i zrozumienie między narodami i kulturami oraz wychowanie młodzieży narodził się w Europie i rozwijany był przez Międzynarodowy Komitet Olimpijski i Europejskie Komitety Olimpijskie" (Biała księga na temat sportu, 2007: 21).

Pojęcie sportu oznacza „wszelkie formy aktywności fizycznej, które poprzez uczestnictwo doraźne lub zorganizowane, stawiają sobie za cel wypracowanie lub poprawienie kondycji fizycznej i psychicznej, rozwój stosunków społecznych lub osiągnięcie wyników sportowych na wszelkich poziomach" (Biała księga na temat sportu, 2007: 14).

W sferze sportu działają liczne organizacje sportowe o różnym charakterze. Są wśród nich np. kluby, a także organizacje pozarządowe, takie jak fundacje. Z analizy literatury z zakresu zarządzania wynika, iż każda organizacja, w tym sportowa, potrzebuje lidera, który będzie inspiracją do dalszych działań.

Pojęcie lidera „pochodzi od angielskiego słowa lead, które oznacza tyle co: prowadzić, przewodzić, kierować, dowodzić, przekonywać. W pierwotnej wersji pojęcie to funkcjonowało w socjologii wychowania jako "przewodnik grupy». Natomiast w pedagogice określa osobę, która cieszy się autorytetem pozwalającym jej wpłynąć na grupę. Do najbardziej pożądanych cech, jakimi powinien wyróżniać się nowoczesny lider, należą: indywidualność, inicjatywa, inspiracja, zaangażowanie, improwizacja, umiejętności realizacyjne, umiejętności komunikacyjne, obiektywizm wobec członków grupy" (Blanchard, Miller, 2008: 51). Do umiejętności lidera należy zdolność do tworzenia zespołów i ułatwianie im rozwoju. Poza tym istotnym elementem strategii lidera jest umiejętność rozpoznawania mocnych 
stron członków zespołów i wykorzystywanie ich do skutecznego rozwiązywania zadań zespołowych (Blanchard, Miller, 2008: 56). Lidera wyróżnia też otwartość i podatność na zmiany. Obowiązkiem lidera jest racjonalna ocena, w jakiej mierze akceptacja zmiany może przyczynić się do korzystnego rozwoju grupy. Wprowadzenie zmiany przez lidera wymaga akceptacji ze strony grupy.

Liderzy są narażeni na częstą krytykę. Jednak, jeśli wykonują swoją rolę przywódczą właściwie, mogą długo z dobrym skutkiem sprawować swoje funkcje.

Bycie liderem determinowane jest wieloma czynnikami.

Uwarunkowania natury zewnętrznej i wewnętrznej lidera stanowią:

1. Czynniki zewnętrzne to środowisko bliższe (rodzina) i dalsze (lokalne, wieś, miasto), ogólna sytuacja społeczna, gospodarcza, polityczna w kraju.

2. Czynniki wewnętrzne:

a) wiedza i umiejętności - zdobyte w procesie kształcenia na różnym poziomie i doświadczenie;

b) kompetencje wyznaczone właściwościami umysłu i osobowości i związane z tym umiejętności. Do najważniejszych zaliczyć należy:

- spostrzegawczość i plastyczność myślenia;

- pozytywne myślenie (ocenianie ludzi);

- łatwość motywowania siebie i innych do działania;

- wysoka inteligencja emocjonalna;

- kontrolowanie swoich emocji w sytuacji niepowodzeń i zagrożeń;

- cierpliwość i upór (Smoleński, 2002: 56).

Wymienione grupy czynników i ich specyfikacja stanowią podstawę oceny możliwości i efektywności funkcjonowania konkretnej osoby w roli lidera. Im wyższa jakość każdego z tych czynników, tym większe prawdopodobieństwo, że ktoś jest bardzo dobrym liderem lub że ktoś, podejmując się roli lidera, będzie funkcjonował w tej roli na bardzo wysokim poziomie.

\section{Trenerzy jako liderzy swoich zespołów}

\subsection{Role i umiejętności trenera}

Praca trenera ma w zasadzie charakter indywidualny, chociaż w związku z zawężeniem się specjalizacji szkoleniowych często zdarza się, że grupa trenerów wspólnie opracowuje i prowadzi szkolenie. Cechy osobowościowe, jakie powinien przejawiać trener w swojej pracy, to: zdyscyplinowanie, pracowitość, uczciwość, obiektywność, cierpliwość i oczywiście wiedza trenerska. Musi być niezwykle konsekwentny w działaniu. 
Jako negatywne cechy, które dyskredytują do tego zawodu, najczęściej wymienia się: wulgarność, brak odpowiedniej wiedzy, brak obiektywizmu wobec zawodników, niezdecydowanie, konfliktowość, brak konsekwencji w działaniu, arogancja względem zawodników oraz niesystematyczność (Czajkowski, 1994: 15).

Trener pełni funkcje życzliwego doradcy. Wyjaśnia wątpliwości, służy radą, pomocą, ułatwia poznanie zasad i metod postępowania. Uczy swoich zawodników samodzielnego myślenia, działania i umiejętności podejmowania decyzji. Tworzy specyficzną więź z zespołem, będąc doradcą i przyjacielem swoich podopiecznych (Naglak, 1999: 49-50).

Trener planuje i kontroluje przebieg odpoczynku sportowca. Trener jest współtwórcą sukcesu sportowego (Czajkowski, 1994: 18).

Jednak we współczesnym sporcie rola trenera nie sprowadza się tylko i wyłącznie do szkolenia zawodników, by osiągali jak najlepsze sukcesy i wyniki - czy to indywidualne, czy też w grach zespołowych. Trener w związku ze swoimi obowiązkami zawodowymi pełni wiele różnych ról społecznych oraz wykonuje zadania, które przekraczają zakres obowiązków. Musi przybrać rolę przywódcy, ojca/ matki, czasem dyktatora, polityka stratega, a także rzecznika odpowiadającego za przekazywanie informacji i utrzymywanie kontaktów ze szkołą, władzami klubu i związku. Trenerem może zostać osoba, która ma minimum średnie wykształcenie i odpowiednią specjalizację.

„Sukcesy trenera zależą w dużej mierze od dojrzałości i zrównoważenia jego osobowości. W badaniach psychologicznych nad trenerem wymienia się cechy niezbędne w powodzeniu w pracy trenera. Do nich zalicza się: zdolność przewodzenia, odpowiedzialność, równowagę emocjonalną, bliskie związki emocjonalne z zawodnikiem, ambicję" (Czajkowski, 1996: 9). Bardzo często trenerzy wywodzą się spośród byłych sportowców. Odnosząc się do specyfiki trenowania przez trenera drużyny osób z niepełnosprawnością intelektualną, należy podkreślić ich własności oraz zjawisko marginalizacji sportu w wymiarze ekonomicznym, medialnym i społecznym (Niedbalski, Racław, Żuchowska-Skiba, 2017: 41).

\section{Specyfika trenowania drużyny dorosłych osób z niepełnosprawnością intelektualną na przykładzie Fundacji im. Brata Alberta w kodzi}

Sport przyczynia się w znacznym stopniu do spójności gospodarczej i społecznej oraz do większej integracji społeczeństw. 


\begin{abstract}
Wszyscy obywatele powinni mieć dostęp do sportu. Należy zająć się szczególnymi potrzebami i sytuacją grup, które nie są wystarczająco reprezentowane; należy uwzględnić szczególną rolę, którą sport może odegrać dla młodych ludzi, ludzi niepełnosprawnych oraz osób z mniej uprzywilejowanych środowisk. Sport może również sprzyjać integracji imigrantów i osób obcego pochodzenia w społeczeństwie oraz wspomagać dialog międzykulturowy. Ponadto Komisja zachęca państwa członkowskie i organizacje sportowe do uwzględnienia potrzeb osób niepełnosprawnych przy dostosowywaniu infrastruktury sportowej. Państwa członkowskie i władze lokalne powinny zapewnić dostępność infrastruktury sportowej dla osób niepełnosprawnych (Biała księga na temat sportu, 2007: 22).
\end{abstract}

Należy przyjąć szczególne kryteria zapewniające równy dostęp do sportu wszystkim uczniom, szczególnie dzieciom niepełnosprawnym. Propagowane będzie szkolenie instruktorów, wolontariuszy i pracowników przyjmujących, w celu przygotowania ich na przyjęcie osób niepełnosprawnych. W konsultacjach przeprowadzanych z zainteresowanymi stronami Komisja zwraca szczególną uwagę na utrzymanie dialogu z przedstawicielami sportowców niepełnosprawnych.

\title{
3.1. Geneza powstania Fundacji im. Brata Alberta
}

Fundacja im. Brata Alberta została założona 21 maja 1987 roku przez Zofię Tetelowską (ur. w 1921 r., zm. w 2003 r.) z Radwanowic, która przekazała swój rodzinny dwór wraz z gospodarstwem rolnym na rzecz osób z niepełnosprawnością intelektualną. Współzałożycielami tego dzieła byli śp. Stanisław Pruszyński (zm. w 1988 r.) i ks. Tadeusz Isakowicz-Zaleski, kapelan „Solidarności” i rodzin osób niepełnosprawnych.

Fundamentem działań Fundacji im. Brata Alberta jest tak zwana idea albertyńska zapoczątkowana przez Adama Chmielowskiego (później św. Brata Alberta). Idea ta głosi szeroko rozumianą pomoc najbardziej potrzebującym, czyli osobom opuszczonym, wzgardzonym, bezdomnym.

Niesienie pomocy osobom niepełnosprawnym intelektualnie jest „podstawowym celem Fundacji, który realizowany jest poprzez organizowanie i prowadzenie specjalistycznych placówek rehabilitacyjnych oraz opiekuńczych dziennego i stałego pobytu" (Statut Fundacji im. Brata Alberta, 1989).

Fundacja im. Brata Alberta prowadzi w Łodzi Dom Stałego Pobytu dla 19 mężczyzn niepełnosprawnych intelektualnie. Od samego początku istnienia Domu zwracano uwagę na zajęcia sportowe jako element terapii i wychowania. W 1993 roku Fundacja przystąpiła do Stowarzyszenia Olimpiady Specjalne Polska, tworząc sekcję, czyli klub sportowy pod nazwą „Helenówek”. Dynamiczny rozwój sekcji datuje się od roku 1995 r., kiedy opiekę sportową nad mieszkańcami przejął dyrektor Domu mgr Jan Bujnowicz. Do dnia dzisiejszego przedstawiciele Domu 
czterokrotnie z dużym powodzeniem reprezentowali Polskę na arenach Europy i Ameryki Północnej. Zdobywali wiele medali na Letnich i Zimowych Ogólnopolskich Igrzyskach Olimpiad Specjalnych. Uczestniczyli we wszystkich zawodach sportowych organizowanych przez Olimpiady Specjalne Polska rozgrywanych na szczeblu wojewódzkim.

\subsection{Terapia poprzez sport}

Terapią przez sport objęci są wszyscy pensjonariusze Fundacji. Ćwiczenia są prowadzone indywidualnie lub w grupach w zależności od stopnia sprawności podopiecznych. Zajęcia ogólnorozwojowe i usprawniające ruchowo odbywają się na boisku Fundacji - podopieczni trenują lekkoatletykę oraz korzystają ze stołu do tenisa stołowego wraz z wyposażeniem, trambambuli czy zestawu elektronicznego do rzutek. Dodatkowo, raz w tygodniu, podopieczni uczęszczają na basen (ćwiczenia w wodzie, nauka pływania). Podstawowym założeniem programu terapii jest usportowienie.

Osoby z niepełnosprawnością intelektualną przeżywają poczucie mniejszej wartości własnej, ponieważ ich niedoskonałość polega najczęściej na gorszym funkcjonowaniu sfery intelektualnej, natomiast mogą z powodzeniem kompensować własną samoocenę przez sukcesy sportowe.

Systematycznie uprawiany sport angażuje nadmiar energii oraz redukuje dynamikę popędów, co w sytuacji mieszkańców Domu jest niezwykle istotne (Dokumentacja terapeutyczna Fundacji im. Brata Alberta).

Często podkreśla się rolę sportu w kształtowaniu kultury rywalizacji. Ta właściwość sportu stanowi ważny element $\mathrm{w}$ formowaniu charakteru osób niepełnosprawnych intelektualnie.

Fundacja jest członkiem Stowarzyszenia Olimpiady Specjalne Polska i wszyscy pensjonariusze należą do sekcji sportowej Olimpiad Specjalnych. Jako zawodnicy startowali już w wielu zawodach sportowych.

Bardzo istotny w Fundacji jest sport drużynowy. „Głównie nacisk kładzie się na trening piłki nożnej - 7-osobowej. Pensjonariusze od kilku lat trenują w tym samym zespole piłkarskim «Helenówek», uczą się techniki i taktyki, poznając nowe rozwiązania ze świata futbolu" (Dokumentacja terapeutyczna Fundacji im. Brata Alberta).

Sport drużynowy to „sport, w którym gracze współdziałają dla osiągnięcia wspólnego celu. Niektóre z nich są rozgrywane między przeciwnymi drużynami, w których gracze współpracują bezpośrednio i jednocześnie dla osiągnięcia celu. Celem najczęściej jest ułatwienie przemieszczenia piłki zgodnie z regułami, aby zyskać punkty" (Palmowska, 2017: 1). 


\subsection{Trener liderem drużyny niepełnosprawnych}

Trener sportowy jest czynnym piłkarzem czwartoligowego MKP Boruty Zgierz. Jako żywy autorytet wspólnie z podopiecznymi z Fundacji poszerzył wiedzę teoretyczną i praktyczną zawodników. Przełożyło się to na jego postawę, osobowość, poczucie własnej wartości i potrzeby w życiu społecznym oraz stosunek do samej placówki. Pod jego kierunkiem zawodnicy Fundacji stali się najlepszą drużyną piłkarską województwa. Od 2013 r. są pierwszymi w Polsce zawodnikami niepełnosprawnymi intelektualnie, który uprawiają piłkę nożną w profesjonalnym klubie piłkarskim MKP Boruta Zgierz. Pensjonariusze są rozpoznawalni i mają poczucie własnej wartości. Wielokrotnie uczestniczyli w treningach pierwszoligowych drużyn łódzkich jako zaproszeni do współpracy partnerzy.

$\mathrm{W}$ pracy trenerskiej dorosłych osób $\mathrm{z}$ niepełnosprawnością intelektualną szczególna uwaga winna być skierowana na indywidualne podejście do zawodników poszczególnych formacji. Trener opisywanej drużyny zawsze stara się mieć to na uwadze. Interesuje się sprawami członków drużyny, rozmawia z nimi, pyta o formę sportową, o trudności, jakie poszczególne osoby napotykają podczas szkolenia. Stara się każdego motywować do wysiłku, dostosowując sposoby pobudzania motywacji do potrzeb i oczekiwań jednostek.

Trener uczy dorosłych niepełnosprawnych piłkarzy gry zespołowej, poznawania ich silnych stron. Pokazuje, że mimo niepełnosprawności, mają wiele do zaoferowania sobie i otoczeniu. Stara się integrować drużynę. Stwarza sportowcom warunki do zdobywania doświadczenia - nie tylko sportowego (piłkarskiego), ale i życiowego. Przekazuje im swoją wiedzę i poglądy. Współpraca trenera z zespołem dorosłych niepełnosprawnych intelektualnie piłkarzy jest możliwa dzięki jego sprawności, umiejętnościom i wiedzy z zakresu sportu, psychologii oraz znajomości jednostek chorobowych swoich zawodników. Ma on także zmysł obserwacji, potrafi analizować sytuacje i wyciągać wnioski. Jest cierpliwy i odporny na stres. Ma umiejętność jasnego komunikowania się z graczami; nakreśla im wizję gry, wskazuje cele i zadania. Zachęca do działania. Bez prawidłowej komunikacji nie byłoby sukcesów drużyny.

\section{Podsumowanie}

Artykuł jest próbą przedstawienia roli trenera jako lidera sportowców z niepełnosprawnością intelektualną. Wskazałem, jakimi cechami powinien odznaczać się lider w każdej organizacji. Dalej opisałem wymagania stawiane trenerom. Zestawienie wymogów stawianych przywódcom oraz szkoleniowcom w sporcie odnalazłem w charakteryzowanym trenerze zespołu piłkarskiego, w skład którego 
wchodzą osoby niepełnosprawne intelektualnie. Teraz pozostawiam do analizy, refleksji i dyskusji kwestię trenowania osób z niepełnosprawnością intelektualną w Polsce - stan obecny oraz podejmowane pierwsze próby tworzenia drużyn osób z niepełnosprawnością intelektualną i koniecznych do prowadzenia takich zespołów cech osobowościowych trenera.

Piłkarze z niepełnosprawnością intelektualną potrzebują ciepła i zrozumienia, nie zawsze mogą liczyć na najbliższych. Uprawianie sportu - w tym przypadku piłki nożnej - daje im możliwość wewnętrznej walki z własnymi słabościami. Trener osób z niepełnosprawnością intelektualną jest szczególnie odpowiedzialny za wyniki sportowe swoich zawodników. Posiada wiele umiejętności zarówno tych merytorycznych, pozwalających realizować szkolenie sportowe, jak i tych umożliwiających i ułatwiających pracę z ludźmi. Powinien być sprawiedliwy, cierpliwy, empatyczny.

Do najczęstszych problemów, z jakimi borykają się trenerzy osób niepełnosprawnych, należą bariery psychiczne wynikające z niepełnosprawności intelektualnej podopiecznych oraz charakter poszczególnych zawodników w zespole. Trenerzy w różny sposób rozwiązują pojawiające się problemy i jeśli udaje im się pokonywać przeciwności, są $\mathrm{w}$ stanie realizować nawet najtrudniejsze zadania. Rola trenera jest niezwykle trudna. Wymaga poświęcenia się swoim obowiązkom.

Trener nigdy nie ma całkowitej pewności, że zawodnik niepełnosprawny, dla którego poświęca swój czas i siły, spełni pokładane w nim nadzieje. Mimo to powinien konsekwentnie realizować proces szkoleniowy.

Niepełnosprawni zawodnicy doceniają pracę trenera, kiedy widzą i doświadczają sami, że mogą pokonać i pokonują własne przeciwności.

Podsumowując, warto dodać, że niezbędne jest organizowanie szkoleń, seminariów, spotkań, podczas których trenerzy osób z niepełnosprawnością mogliby wymienić swoje myśli, doświadczenia, pomysły, zapoznawać się z nowymi formami i metodami pracy trenerskiej w kraju i zagranicą. Potrzebna jest również fachowa literatura dotycząca sportów zespołowych, z których mogliby skorzystać nie tylko trenerzy, ale i rodzice osób z niepełnosprawnością intelektualną chcący umożliwić dzieciom, również tym dorosłym - „pełnosprawnym obywatelom” - większe możliwości rozwoju.

\section{Bibliografia}

Biała księga na temat sportu, COM (2007), 391 wersja ostateczna, Komisja Wspólnot Europejskich, Bruksela, 11.07.2007 r.

Blanchard K., Miller M. (2008), Sekret. Tajemnica wielkich liderów, Warszawa.

Czajkowski Z. (1994), Poradnik trenera, Warszawa. 
Czajkowski Z. (1996), Psychologia sprzymierzeńcem trenera, Warszawa.

Dokumentacja terapeutyczna Fundacji im. Brata Alberta.

Griffin R.W. (2009), Podstawy zarządzania organizacjami, Warszawa.

Koźmiński A.K., Jemielniak D. (2008), Zarządzanie od podstaw. Podręcznik akademicki, Warszawa.

Kożusznik B. (2005), Wpływ społeczny w organizacji, Warszawa.

Melosik Z. (2013), Kultura popularna i tożsamość młodzieży, Kraków.

Naglak Z. (1999), Metodyka trenowania sportowca, Wrocław.

Niedbalski J., Racław M., Żuchowska-Skiba D. (red.) (2017), Oblicza niepełnosprawności w teorii i praktyce, Łódź.

Palmowska N. (2017), Podstawowe wytyczne żywieniowe w sportach drużynowych, Body Challenge, nr 12.

Smoleński S. (2002), Lider zespołu, Bydgoszcz.

Statut Fundacji im. Brata Alberta (1989), Kraków. 